\title{
LITERASI KEUANGAN, FAKTOR DEMOGRAFI DAN AKSES PERMODALAN PENGARUHNYA TERHADAP KEPUTUSAN PENGAMBILAN KREDIT USAHA SEKTOR INFORMAL
}

\author{
Akhmad Darmawan', Dini Fatiharani2 \\ Manajemen, Universitas Muhammadiyah Purwokerto \\ Purwokerto,Indonesia \\ akhmaddarmawan@ump.ac.id,fatiharanidini@gmail.com
}

\begin{abstract}
This study aims to anlyze effect of financial literacy, demographics factor (age, income, employment, education) and acces toward credit investment decision on informal sector business in West Purwokerto District. Sample in this study were 202 people taken by purposive sampling method. Data were analyzed using descriptive statistics test, validity test, reliability test, classical assumption test and multiple linear regression analysis. The results showed that financial literacy, employment, and access to capital have sign toward credit investment decision, education has an insignificantly positive effect toward credit investment decision. While both age and income have significantly negative effect toward credit investment decision.
\end{abstract}

Keywords:Financial Literacy, Demographic Factors, Capital Access, Decision to take investment credit

\begin{abstract}
Abstrak
Tujuan penelitian ini adalah untuk menguji faktor-faktor yang mempengaruhi keputusan pengambilan kredit usaha pada pelaku usaha sektor informal di Kecamatan Purwokerto Barat, yang terdiri dari literasi keuangan, faktor demografi (usia, pendapatan, pekerjaan, pendidikan) dan akses permodalan. Sampel pada penelitian ini sejumlah 202 orang yang diambil dengan purposive sampling. Teknik analisa data menggunakan uji statistik deskriptif, uji validitas, uji reliabilitas, uji asumsi klasik dan regresi linier berganda. Hasil penelitian ini menunjukkan bahwa literasi keuangan, pekerjaan dan akses permodalan berpengaruh positif dan signifikan terhadap keputusan pengambilan kredit usaha, pendidikan berpengaruh positif dan tidak signifikan terhadap keputusan pengambilan kredit usaha. Sedangkan usia berpengaruh negatif dan signifikan terhadap keputusan pengambilan kredit usaha dan pendapatan memiliki pengaruh negatif dan tidak signifikan terhadap keputusan pengambilan kredit usaha.
\end{abstract}

Kata kunci : Literasi Keuangan, Faktor Demografi, Akses Permodalan, Keputusan pengambilan kredit usaha.

\section{PENDAHULUAN}

Saat ini, sektor informal menjadi bagian penting dalam perumusan kebijakan ketenagakerjaan. Sektor informal merupakan salah satu alternatif kesempatan kerja yang mampu menampung tenaga kerja tanpa persyaratan tertentu seperti tingkat pendidikan dan keterampilan kerja. Hal ini merupakan salah satu faktor utama yang memudahkan tenaga 
Jurnal Manajemen Bisnis, Vol 10. No.1, Maret 2019, E-ISSN:2622-6308 P-ISSN:2086-8200

Website: http://journal.umy.ac.id/index.php/mb

DOI:10.18196/mb.10169

kerja memasuki sektor ini dan semakin mengukuhkan kehadirannya sebagai penyangga terhadap kelebihan tenaga kerja. Dalam beberapa hal, sektor informal lebih dapat beradaptasi dan tidak terganggu oleh manajemen operasional yang kaku (Made, 2015).

Sektor informal mengisi setidaknya dua pertiga dari perekonomian nasional. Struktur ini merupakan bagian strategis di dalam sistem, tetapi sekaligus merupakan masalah yang rumit. Beberapa masalah yang timbul antara lain : Keterbatasan modal dan akses terhadap pasar merupakan kendala utama yang bersifat akut dan belum bisa tertanggulangi secara sempurna (Nasution, 2016).

Penggunaan modal pada sektor informal relatif sedikit bila dibandingkan dengan sektor formal sehingga cukup dengan modal sedikit dapat memperkerjakan orang. Pembentukan modal merupakan faktor yang penting dan strategis serta menjadi salah satu faktor kunci dalam proses ekonomi. Salah satu tahapan yang harus ditempuh agar proses tersebut dapat berjalan adalah perlunya keberadaan lembaga kredit dan keuangan untuk menggalakkan dan menyalurkan dana kepada usaha mikro.

Salah satu bentuk kredit yang ditawarkan kepada masyarakat adalah Kredit Usaha Rakyat (KUR), berdasarkan peraturan pemerintah nomor 135/PMK 05/2008 Kredit Usaha Rakyat (KUR) merupakan kredit/pembiayaan modal kerja dan atau investasi yang khusus diperuntukkan bagi Usaha Mikro Kecil Menengah dan Koperasi (UMKMK) di bidang usaha produktif dan layak (feasible), namun mempunyai keterbatasan dalam pemenuhan persyaratan yang ditetapkan Perbankan (belum bankable). Pengajuan permohonan peminjaman Kredit Usaha Rakyat (KUR) tentu saja harus mengikuti berbagai prosedur yang ditetapkan oleh bank yang bersangkutan. Selain itu, pemohon harus mengetahui hak dan kewajiban yang akan timbul dari masing-masing pihak yaitu debitur dan kreditur (Hanifah, 2015).

Penelitian ini mengacu pada penelitian yang dilakukan oleh Hidayanti dan Karta winata (2017). Objek yang digunakan adalah Pelaku Usaha Sektor Informal di Kecamatan Purwokerto Barat. Berdasarkan latar belakang diatas, maka penelitian ini bertujuan untuk menganalisis "Pengaruh Literasi Keuanga, Faktor Demografi dan Akses Permodalan Terhadap Keputusan Pengambilan Kredit Usaha Pada Pelaku Usaha Sektor Informal di Kecamatan Purwokerto Barat". 
Jurnal Manajemen Bisnis, Vol 10. No.1, Maret 2019, E-ISSN:2622-6308 P-ISSN:2086-8200

Website: http://journal.umy.ac.id/index.php/mb

DOI:10.18196/mb.10169

\section{Tujuan Penelitian}

Tujuan penelitian ini adalah untuk mengetahui: (1) pengaruh literasi keuangan, faktor demografi dan akses permodalan secara simultan mempengaruhi keputusan pengambilan kredit usaha, (2) pengaruh positif dan signifikan literasi keuangan terhadap keputusan pengambilan kredit usaha, (3) pengaruh negatif dan signifikan usia terhadap keputusan pengambilan kredit usaha, (4) pengaruh positif dan signifikan pendapatan terhadap keputusan pengambilan kredit usaha, (5) pengaruh negatif dan signifikan pekerjaan terhadap keputusan pengambilan kredit usaha, (6) pengaruh positif dan signifikan pendidikan terhadap keputusan pengambilan kredit usaha, (7) pengaruh positif dan signifikan akses permodalan terhadap keputusan pengambilan kredit usaha.

\section{KAJIAN TEORI}

\section{Keputusan Pengambilan Kredit}

Keputusan pengambilan kredit merupakan suatu tindakan keputusan untuk mengambil suatu kepercayaan (kredit) yang diberikan oleh suatu lembaga (bank dan non bank) dengan syarat yang telah disepakati (Kurnawan, Suryoko dan Listyarini, 2016). Teori yang mendasari keputusan pengambilan kredit adalah pecking order theory. Teori ini menjelaskan bahwa perusahaan/perorangan mempunyai urutan preferensi dalam memilih sumber pendanaan dengan mempertimbangkan biaya termurah dan risiko paling kecil (Myers, Stewart C.; Majluf, Nicholas S, 1984). Menurut Brealey RA, Myers SC, and Allen F (2008) ; Wijayanto (2015). kepuasan nasabah dalam mengambil kredit dipengaruhi oleh; (1) bukti fisik, (2) jaminan, (3) ketanggapan, (4) keandalan, (5)perhatian dan kepuasan Menurut Wiryaningtyas (2016) faktor yang mempengaruhi keputusan nasabah dalam mengambil kredit adalah faktor kebudayaan, faktor sosial dan faktor psikologis.

\section{Literasi Keuangan}

Otoritas Jasa keuangan (OJK, 2018) Literasi Keuangan adalah rangkaian proses atau aktivitas untuk meningkatkan pengetahuan (knowledge), keyakinan (confidence), keterampilan (skill) konsumen dan masyarakat luas sehingga mereka mampu mengelola keuangan dengan lebih baik. Literasi keuangan dibagi menjadi empat aspek yang terdiri dari pengetahuan dasar keuangan (basicfiancial knowladge), simpanan dan pinjaman (saving $\mathcal{E}$ borrowing), proteksi (insurance), dan investasi. Literasi keuangan dilandasi oleh theory of 
Jurnal Manajemen Bisnis, Vol 10. No.1, Maret 2019, E-ISSN:2622-6308 P-ISSN:2086-8200

Website: http://journal.umy.ac.id/index.php/mb

DOI:10.18196/mb.10169

planed behavior yang menyatakan bahwa seseorang dalam melakukan beberapa perilaku karena memiliki niat atau tujuan dalam melakukannya dengan dilatarbelakangi oleh beberapa faktor diantaranya faktor informasi yang salah satunya pengetahuan keuangan (Hidajat, 2015).

\section{Faktor Demografi}

Faktor demografi adalah faktor yang melekat pada diri seseorang dan membedakan antara individu satu dengan individu lainnya.faktor demografi termasuk status pekerjaan, status perkawinan, pendapatan, pekerjaan, usia, jenis kelamin, pengalaman pekerjaan dan tingkat pendidikan (Aminatuzzahra, 2014).

Usia adalah batasan atau tingkat ukuran hidup yang mempengaruhi kondisi fisik seseorang (Iswantoro dan Anastasia, 2013). Menurut kamus besar bahasa Indonesia, pendapatan individu yang mempunyai makna hasil yang mempunyai definisi sesuatu yang diadakan, dibuat, dijadikan oleh usaha. Pekerjaan dapat diartikan profesi yang disandang seseorang dalam melakukan aktifitas yang memberikan hasil baik berupa pengalaman atau materi yang dapat menunjang kehidupannya (Iswantoro dan Anastasia, 2013).

Menurut Undang - Undang Republik Indonesia Pasal 1 Nomor 20 Tahun 2003 tentang Pendidikan Nasional, pendidikan merupakan usaha sadar dan terencana untuk mewujudkan suasana belajar dan proses pembelajaran agar peserta didik secara aktif mengembangkan potensi dirinya. Pendidikan didasari oleh teori pengambilan keputusan (decision making) dimana salah satu tahap dakam pengambilan keputusan ada faktor intellegence (Fahmi, 2016;2).

\section{Akses Permodalan}

Menurut Mardiyatmo (2008) mengatakan bahwa modal dibedakan menjadi 2 yakni, modal sendiri dan modal pinjaman. Modal sendiri adalah modal yang diperoleh dari pemilik usaha itu sendiri. Modal sendiri terdiri dari tabungan, sumbangan, hibah, saudara, dan lain sebagainya. Modal asing atau modal pinjaman adalah modal yang biasanya diperoleh dari pihak luar perusahaan dan biasanya diperoleh dari pinjaman. 
Jurnal Manajemen Bisnis, Vol 10. No.1, Maret 2019, E-ISSN:2622-6308 P-ISSN:2086-8200

Website: http://journal.umy.ac.id/index.php/mb

DOI:10.18196/mb.10169

\section{HIPOTESIS}

\section{Pengaruh Literasi Keuangan Terhadap Keputusan Pengambilan Kredit Usaha}

Literasi keuangan terdiri dari sejumlah kemampuan dan pengetahuan mengenai keuangan yang dimiliki oleh seseorang untuk mampu mengelola atau menggunakan sejumlah uang untuk meningkatkan taraf hidupnya dan bertujuan untuk mencapai kesejahteraan (Lusardi, 2014). Pengetahuan keuangan masyarakat dapat dilihat dari seberapa besar tingkat literasi keuangan yang dimilikinya. Semakin tinggi tingkat literasi keuangan yang dimiliki seorang maka semakin tepat dalam menentukan pengambilan pada produk keuangan khususnya dengan sistem kredit dan nantinya mampu menghindari dari risiko keuangan (Margaretha dan Arief , 2015). Penjelasan tersebut didukung oleh penelitian yang dilakukan beberapa peneliti seperti Tsalitasa dan Rachmansyah (2016), Hidayanti dan Kartawinata (2017), Lusimbo (2016), Andriani, Cholid dan Kardinal (2016) menunjukkan bahwa literasi keuangan berpengaruh positif dan signifikan terhadap keputusan pengambilan kredit.

H1 : Literasi Keuangan berpengaruh positif dan signifikan terhadap Keputusan Pengambilan Kredit Usaha

\section{Pengaruh Usia terhadap Keputusan Pengambilan Kredit Usaha}

Faktor usia berperan penting dalam mengambil keputusan salah satunya keputusan dalam menentukan produk dan jasa keuangan secara tepat. Semakin matang usia seseorang maka perilaku dalam mengambil keputusan akan semakin bijak dan berhati hati. (Andriani, Cholid dan Kardinal, 2016). Semakin matang atau tua seseorang semakin hati hati bahkan tidak berani mengambil kredit pinjaman, masa usia tua menginginkan rasa nyaman dan ketenangan dalam menjalani aktivitas sehari-hari (Tsalitsa dan Rachmansyah, 2016). Penjelasan tersebut didukung oleh penelitian yang dilakukan beberapa peneliti seperti, penelitian Sadiq dan Ishaq (2014), Tsalitsa dan Rachmansyah (2016), Chandio et al (2017), Saqib et al ( 2017) menunjukkan bahwa usia berpengaruh negatif dan signifikan terhadap keputusan pengambilan kredit.

H2: Usia berpengaruh negatif dan signifikan terhadap Keputusan Pengambilan Kredit Usaha 
Jurnal Manajemen Bisnis, Vol 10. No.1, Maret 2019, E-ISSN:2622-6308 P-ISSN:2086-8200

Website: http://journal.umy.ac.id/index.php/mb

DOI:10.18196/mb.10169

\section{Pengaruh Pendapatan Terhadap Keputusan Pengambilan Kredit Usaha}

Pendapatan menjadi faktor paling utama yang dipertimbangkan seseorang dalam mengalokasikan pengeluarannya salah satunya mempengaruhi seseorang dalam mengambil keputusan untuk pengambilan kredit. Penelitian Tsalitsa dan Rachmansyah (2016) menunjukkan bahwa pendapatan berpengaruh positif dan signifikan terhadap keputusan pengambilan kredit. Penelitian ini juga di dukung oleh Andriani, Cholid dan Kardinal (2016) Chandio et al (2017), Chrisanti dan Saryad (2017), menunjukkan bahwa pendapatan berpengaruh positif dan signifikan terhadap keputusan pengambilan kredit.

H3 : Pendapatan berpengaruh positif dan signifikan terhadap Keputusan Pengambilan Kredit Usaha

\section{Pengaruh Pekerjaan Terhadap Keputusan Pengambilan Kredit Usaha}

Pekerjaan yang dilakukan seseorang akan mempengaruhi presepsi dan sikap dalam memenuhi kebutuhannya baik pekerjaan di bidang akademik maupun non akademik. Pada pekerjaan dibidang ekonomi akan terlihat lebih berhati-hati dan detail dalam melakukan perhitungan matematis bahkan dalam mengambil kredit. Penelitian Tsalitsa dan Rachmansyah (2016), Sadiq dan Ishaq (2014) juga menunjukkan bahwa pekerjaan berpengaruh negatif dan signifikan terhadap keputusan pengambilan kredit.

H4 : Pekerjaan berpengaruh negatif dan signifikan terhadap Keputusan Pengambilan Kredit Usaha

\section{Pengaruh Pendidikan Terhadap Keputusan Pengambilan Kredit Usaha}

Pendidikan berpengaruh dalam pengambilan keputusan seseorang, semakin tinggi tingkat pendidikan semakin banyak pengetahuan sehingga dalam pengambilan keputusan didasarkan pada analisis yang mendalam seperti keputusan mengambil kredit dengan memperhatikan prosedur pembayaraan serta bunga (Andriani, Cholid, Kardinal, 2016). Pernyataan ini sesuai dengan penelitiannya Nikaido, Paqis \& Sarma (2015), Saqib et al ( 2017), Chandio et al (2017) yang menunujukkan bahwa pendidikan berpengaruh positif dan signifikan terhadap keputusan pengambilan kredit.

H5 : Pendidikan berpengaruh positif dan signifikan terhadap Keputusan Pengambilan Kredit Usaha 
Jurnal Manajemen Bisnis, Vol 10. No.1, Maret 2019, E-ISSN:2622-6308 P-ISSN:2086-8200

Website: http://journal.umy.ac.id/index.php/mb

DOI:10.18196/mb.10169

\section{Pengaruh Akses Modal Terhadap Keputusan Pengambilan Kredit Usaha}

Akses modal kredit biasanya condong ke pinjaman informal atau lembaga pembiayaan mikro. pinjaman bank formal ke usaha mikro jarang dilakukan di Indonesia, mengingat fakta bahwa pinjaman bank formal hanya dapat diakses untuk bisnis skala menengah hingga besar yang telah memiliki izin usaha, legalitas dan keuntungan yang tetap dan besar. karakteristik spesifik perusahaan menentukan cara yang paling sesuai untuk perusahaan melakukan pendekatan kredit. Usaha kecil mikro informal harus membiayai bagian investasinya dengan sumber informal, seperti rentenir atau keluarga dan teman atau sangat bergantung pada pinjaman bank jangka pendek, sedangkan perusahaan yang lebih besar memfasilitasi investasi mereka dengan bagian yang lebih besar dari sumber eksternal formal (Farida, Siregar, Nurdiantoro dan Intan, 2015). Penelitian Heikkilä, Kalmi dan Ruuskanen (2016) menunjukkan bahwa modal sosial tingkat individu, yang diukur dengan kuantitas dan kualitas koneksi sosial, memang penting untuk akses ke kredit dari lembaga keuangan. Hasil dari penelitian menunjukkan bahwa modal berpengaruh positif dan signifikkan terhadap akses kredit.

H6: Akses Permodalan berpengaruh positif dan signifikan terhadap Keputusan Pengambilan Kredit Usaha

\section{METODE PENELITIAN}

Penelitian ini menggunakan deskriptif kuantitatif. Pendekatan kuantitatif memusatkan perhatian pada gejala-gejala yang mempunyai karakteristik tertentu didalam kehidupan manusia yang dinamakan sebagai variabel. Dalam pendekatan kuantitatif hakikat hubungan diantara variabel-variabel dianalisis dengan menggunakan teori yang objektif (Sujarweni, 2015).

Populasi dalam penelitian ini adalah pelaku usaha sektor informal di Kecamatan Purwokerto Barat sejumlah 228. Sampel diperoleh dengan menggunakan purposive sampling yaitu teknuk penentuan sampel dengan pertimbangan tertentu. Kriteria sampel dalam penelitian ini adalah sebagai berikut: (1) Usaha yang tidak memiliki legalitas atau badan hukum. (2) Berusaha sendiri dengan bantuan keluarga atau anggota keluarga dengan tidak dibayar. (3) Skala usaha kecil dalam arti jangkauan usahanya tidak luas. (4) Sedang mengambil kredit di lembaga keuangan. 
Jurnal Manajemen Bisnis, Vol 10. No.1, Maret 2019, E-ISSN:2622-6308 P-ISSN:2086-8200

Website: http://journal.umy.ac.id/index.php/mb

DOI:10.18196/mb.10169

Sedangkan untuk perhitungan sampel digunakan Rumus Slovin, dengan rumus sebagai berikut:

$$
\begin{aligned}
& \mathbf{n}=\frac{\boldsymbol{N}}{\mathbf{1 + N ( \boldsymbol { e } ) \mathbf { 2 }}} \\
& \text { dimana : } \\
& \mathrm{n} \quad=\text { jumlah sampel } \\
& N \quad=\text { ukuran Populasi } \\
& \mathrm{e} \quad=\text { batas kesalahan }(5 \%) \\
& \mathrm{n}=\frac{201}{1+201(0,05)^{2}} \\
& \mathrm{n}=134
\end{aligned}
$$

Untuk meminimalisir tidak kembalinya kuesioner, peneliti akan menyebar sejumlah 220 kuisioner.

Jenis data pada penelitian ini adalah data primer. Data primer adalah data yang dikumpulkan sendiri oleh peneliti langsung dari sumber pertama (Suliyanto, 2018). Sumber data diperoleh langsung dari responden melalui kuisioner. Teknik pengumpulan data pada penelitian ini menggunakan kusioner yaitu metode pengumpulan data yang dilakukan dengan cara membagi daftar pertanyaaan kepada responden agar responden tersebut memberikan jawabannya (Suliyanto, 2018).

\section{TEKNIK ANALISIS DATA}

\section{Uji Validitas}

Digunakan untuk mengukur sah atau valid tidaknya suatu kuisioner. Suatu kuisioner dikatakan valid jika pernyataan pada kuisioner mampu untuk mengungkapkan suatu yang akan diukur oleh kuisioner tersebut. Jika r hitung lebih besar dari tabel dan nilai positif maka butir pertanyaan atau indikator tersebut dinyatakan valid (Sujarweni, 2015).

\section{Uji Reliabilitas}

Menurut Ghozali (2016) realibitas sebenarnya adalah alat untuk mengukur suatu kuisioner yang merupakan indikator dari variabel atau konstruk. Suatu kuisioner dikatakan reliable atau handal jika jawaban seorang terhadap pernyataan adalah konsisten dari waktu ke waktu. Suatu variabel dikatakan reliabel jika memiliki Cronbach Alpha $>0.60$ (Sujarweni, 2015). 
Jurnal Manajemen Bisnis, Vol 10. No.1, Maret 2019, E-ISSN:2622-6308 P-ISSN:2086-8200

Website: http://journal.umy.ac.id/index.php/mb

DOI:10.18196/mb.10169

\section{Uji Asumsi Klasik}

\section{Uji Normalitas}

Uji normalitas akan dilakukan dengan menggunakan analisis kolmogorof-smirnov (KS). Uji K-S dalam mengambil kesimpulan untuk menentukan normal atau tidak adalah dengan menilai signifikansinya. Jika signifikan > 0,05 maka variabel berdistribusi normal dan sebaliknya jika signifikansi < 0,05 maka variabel tidak berdistribusi (Sujarweni, 2015).

\section{Uji Multikolonieritas}

Untuk mendeteksi adanya multikolonieritas dengan membuat hipotesis: (1) Tolerance value < 0,10 atau VIF $>10$ : terjadi multikolenearitas. (2) Tolerance value $>0,10$ atau VIF $<10$ : tidak terjadi multikolenearitas .

\section{Uji Heterokesdatisitas}

Uji glejser dilakukan dengan meregresikan semua variabel bebas terhadap nilai mutlak residualnya. Gejala heterokedastisitas ditunjukkan oleh koefisien regresi dari masing-masing variabel bebas terhadap nilai absolut residualnya. Jika nilai probabilitas lebih besar dari nilai alfa (sig.> a), maka dapat dipastikan model tidak mengandung gejala heterokedastisitas atau dikatakan tidak terjadi heterokedastisitas apabila $\mathrm{t}$ hitung lebih kecil dari t tabel (Sullyanto, 2011).

\section{Analisis Regresi Berganda}

Regresi linear berganda untuk mengetahui pengaruh variabel literasi keuangan, faktor Demografi, dan akses permodalan terhadap keputusan pengambilan kredit usaha. persamaan analisis regresi dapat dirumuskan sebagai berikut :

$$
Y=\alpha+\beta_{1} X_{1}+\beta_{2} X_{2}+\beta_{3} X_{3}+\beta_{4} X_{4}+\beta_{5} X_{5}+\beta_{6} X_{6}+e
$$

Keterangan :

$$
\begin{array}{ll}
\mathrm{Y} & =\text { Keputusan pengambilan kredit usaha } \\
\mathrm{a} & =\text { Konstanta } \\
\beta_{1}-\beta_{6} & \quad=\text { Koefisien regresi } \\
\mathrm{X}_{1} & =\text { Literasi keuangan } \\
\mathrm{X}_{2} & =\text { Faktor demografi }: \text { Usia } \\
\mathrm{X}_{3} & =\text { Faktor demografi }: \text { Pendapatan } \\
\mathrm{X}_{4} & =\text { Faktor demografi }: \text { Pekerjaan }
\end{array}
$$


Jurnal Manajemen Bisnis, Vol 10. No.1, Maret 2019, E-ISSN:2622-6308 P-ISSN:2086-8200

Website: http://journal.umy.ac.id/index.php/mb

DOI:10.18196/mb.10169

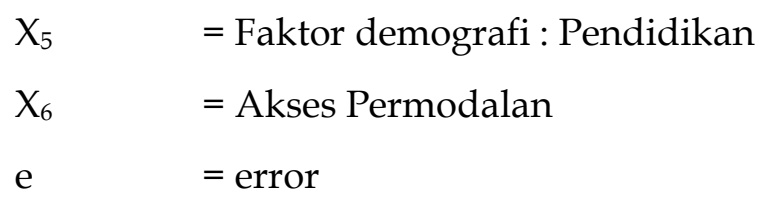

\section{Uji Hipotesis}

\section{Uji Koefisien Determinasi}

Koefisien determinasi $\left(\mathrm{R}^{2}\right)$ mengukur seberapa jauh kemampuan model dalam menerangkan variasi variabel dependen.

\section{Uji F}

Uji F digunakan untuk menunjukkan apakah semua variabel bebas yang dimasukkan dalam model mempunyai pengaruh secara bersama-sama terhadap variabel terikat. Jika nilai signifikan (a) diatas 5\% berarti secara bersama-sama variabel independen tidak mempunyai pengaruh terhadap variabel dependen. Jika nilai signifikan kurang dari $5 \%$ berarti secara bersama-sama variabel dependen mempunyai pengaruh terhadap variabel independen.

\section{Uji t}

Hasil uji t dilihat untuk menunjukkan seberapa jauh pengaruh satu variabel independen secara individual menerangkan variasi variabel dependen (Ghozali, 2016;171). Variabel dikatakan berpengaruh signifikan apabila thitung $>$ ttabel dan nilai signifikan $<0,05$.

\section{HASIL DAN PEMBAHASAN}

\section{Uji Validitas}

Pada uji validitas, diperoleh $\mathrm{r}$ tabel sebesar 0,1161. Dari semua item pernyataan variabel dipeoleh $\mathrm{r}$ hitung diatas 0,1161 . Sehingga semua pernyataan pada kuisioner dapat dikatakan valid.

\section{Uji Reliabilitas}

Pada uji reliabilitas diperoleh nilai Cronbach Alpha Literasi Keuangan 0,726, Faktor Demografi : (Usia 0,613, Pendapatan 0,676, Pekerjaan 0,605, Pendidikan 0,607) Akses Permodalan 0,654 dan Keputusan Pengambilan Kredit Usaha sebesar 0,609. 
Jurnal Manajemen Bisnis, Vol 10. No.1, Maret 2019, E-ISSN:2622-6308 P-ISSN:2086-8200

Website: http://journal.umy.ac.id/index.php/mb

DOI:10.18196/mb.10169

\section{Uji Asumsi Klasik}

\section{Uji normalitas}

Pada uji Kolmogrov-Smirnov, diperoleh nilai asymp.sig sebesar 0,061, nilai tersebut memenuhi ketentuan sig. $(p)>0,05$. Hal ini berarti bahwa data residual berdistribusi normal.

\section{Uji multikolonieritas}

Nilai tolerance masing-masing variabel tidak ada yang dibawah 0,10 (nilai tolerance Literasi Keuangan sebesar 0,779, Faktor Demografi : Usia sebesar 0,766, Pendapatan sebesar 0,839, Pekerjaan sebesar 0,837, Pendidikan sebesar 0,926 dan Akses Permodalan sebesar 0,766). Begitu juga dengan nilai VIF (Literasi Keuangan sebesar 1,283, Faktor Demografi : Usia sebesar 1,305, Pendapatan sebesar 1,192, Pekerjaan sebesar 1,194, Pendidikan sebesar 1,080 dan Akses Permodalan sebesar 1,305.

\section{Uji Heterokesdatisitas}

Nilai signifikansi dari variabel Literasi Keuangan sebesar 0,405, Faktor Demografi : Usia sebesar 0,803, Faktor Demografi : Pendapatan sebesar 0,119, Faktor Demografi : Pekerjaan sebesar 0,277, Faktor Demografi : Pendidikan sebesar 0,344 dan Akses Permodalan sebesar 0,718, maka dapat disimpulkan bahwa data yang digunakan tidak terjadi heterokesdatisitas.

\section{Analisis Regresi Berganda}

\section{Tabel 1. Hasil Uji Regresi Linier Berganda}

\section{Coefficients ${ }^{\mathrm{a}}$}

\begin{tabular}{lllllc}
\hline & \multicolumn{2}{l}{$\begin{array}{l}\text { Unstandardized } \\
\text { Coefficients }\end{array}$} & $\begin{array}{l}\text { Standardized } \\
\text { Coefficients }\end{array}$ & \\
\cline { 2 - 5 } Model & $\mathrm{B}$ & Std. Error Beta & $\mathrm{t}$ & Sig. \\
\hline 1 (Constant) & 2,438 &, 289 & & 8,430 &, 000 \\
\hline Literasi_Keuangan &, 131 &, 065 &, 149 & 2,036 &, 043 \\
\hline Usia &,- 070 &, 034 &,- 154 & $-2,081$ &, 039 \\
\hline Pendapatan &,- 034 &, 040 &,- 060 &,- 851 &, 396 \\
\hline Pekerjaan &, 110 &, 040 &, 195 & 2,756 &, 006
\end{tabular}


Jurnal Manajemen Bisnis, Vol 10. No.1, Maret 2019, E-ISSN:2622-6308 P-ISSN:2086-8200

Website: http://journal.umy.ac.id/index.php/mb

DOI:10.18196/mb.10169

\begin{tabular}{lllllll} 
Pendidikan &, 063 &, 049 &, 087 & 1,292 &, 198 \\
\hline Akses_Permodalan &, 201 &, 047 &, 317 & 4,297 &, 000
\end{tabular}

a. Dependent Variable: Keputusan_Pengambilan

Hasil optimas nilai regresi berganda adalah sebagai berikut:

$$
\begin{aligned}
\mathrm{Y} & =\alpha+\beta_{1} X_{1}+\beta_{2} X_{2}+\beta_{3} X_{3}+\beta_{4} X_{4}+\beta_{5} X_{5}+\beta_{6} X_{6}+e \\
& =2,438+0,149 X_{1}-0,154 X_{2}-0,060 X_{3}+0,195 X_{4}+0,087 X_{5}+0,317 X_{6}+e
\end{aligned}
$$

\section{Uji Hipotesis}

\section{Uji Koefisien determinasi}

Nilai adjusted R Square dari model regresi yang terbentuk dalam penelitian ini adalah sebesar 0,160 yang menunjukkan bahwa kemampuan variabel independen (literasi keuangan, faktor demografi : usia, pendapatan, pekerjaan, pendidikan dan akses permodalan) dalam menjelaskan variabel dependen (keputusan pengambilan kredit usaha) adalah sebesar $16 \%$ sisanya sebesar $84 \%$ dipengaruhi oleh variabel lain.

\section{Uji F}

Diperoleh hasil $F_{\text {hitung }}>F_{\text {tabel }}$ adalah 7,361 > 2,15 dengan tingkat signifikansi 0,000. Karena probabilitas 0,000 jauh lebih kecil dari 0,05 maka model regresi uji $\mathrm{F}$ dapat dipakai untuk memprediksi keputusan pengambilan kredit usaha. Analisis tersebut dapat dikatakan literasi keuangan, faktor demografi: usia, pendapatan, pekerjaan dan pendidikan, dan akses permodalan berpengaruh secara simultan terhadap keputusan pengambilan kredit usaha.

\section{Uji t (lihat tabel 1)}

\section{Pengaruh Literasi Keuangan Terhadap Keputusan Pengambilan Kredit Usaha}

Berdasarkan tabel 1, diperoleh nilai $t_{\text {hitung }} 2,036$ sedangkan $t_{\text {tabel }}$ sebesar 1,652. Hal ini berarti $t_{\text {hitung }}>t_{\text {tabel }}$ sedangkan signifikansi 0,043 kurang dari 0,05. Oleh karena $t_{\text {hitung }}>$ $t_{\text {tabel }}(2,036>1,652)$ artinya secara parsial ada pengaruh positif signifikan antara literasi keuangan terhadap keputusan pengambilan kredit usaha.

Hasil ini menujukkan literasi keuangan yang baik dapat ditunjukkan dengan tingkat pemahaman mengenai produk dan konsep keuangan melalui bantuan informasi dan saran, sebagai kemampuan untuk mengidentifikasi dan memahami risiko keuangan agar dapat mengambil keputusan keuangan secara tepat. Pengetahuan tentang keuangan sangat 
Jurnal Manajemen Bisnis, Vol 10. No.1, Maret 2019, E-ISSN:2622-6308 P-ISSN:2086-8200

Website: http://journal.umy.ac.id/index.php/mb

DOI:10.18196/mb.10169

penting bagi individu, agar mereka tidak salah paham dalam membuat keputusan keuangan salah satunya keputusan pengambilan kredit usaha. Hasil ini selaras dengan penilitian yang dilakukan oleh Nkundabanyanga (2014), Tsalitsa dan Rachmansyah (2016), Lusimbo dan Maturi (2016), Andriani, Cholid dan Kardinal (2017) yang menunjukkan bahwa literasi keuangan berpengaruh positif dan signifikan terhadap keputusan pengambilan kredit usaha. Hasil ini juga didukung oleh Theory of Planned Behavior.

\section{Pengaruh Usia Terhadap Keputusan Pengambilan Kredit Usaha}

Diperoleh nilai $t_{\text {hitung }}-2,081$ sedangkan $t_{\text {tabel }}$ sebesar 1,652. Hal ini berarti $t_{\text {hitung }}<{ }_{\text {ttabel }}$ sedangkan signifikansi 0,039 kurang dari 0,05. Oleh karena $t_{\text {hitung }}<t_{\text {tabel }}(-2,081<1,652)$ artinya secara parsial ada pengaruh negatif signifikan antara faktor demografi : usia terhadap keputusan pengambilan kredit usaha, sehingga hipotesis diterima dan Ho ditolak.

Semakin matang usia yang dimiliki, maka kecenderungan pengambilan kredit akan semakin sedikit. Usia yang semakin tinggi itulah yang membuat seseorang lebih berhati-hati terhadap pengelolaan uang dan memantau pengeluaran untuk melakukan kredit sehingga pengambilan kredit akan semakin turun. Dikarenakan semakin matang usia seseorang akan menyadari bahwa di masa tua mereka tidak menginginkan untuk menghabiskan uang mereka hanya untuk membayar membeli sesuatu yang justru akan menambah beban mereka dengan angsuran kredit. Hasil ini mendukung penelitian yang dilakukan oleh Tsalitsa dan Rachmansyah (2016), Andriani, Cholid dan Kardinal (2016), Chandio et al (2017) dan Mitra dan Prodhan (2018) yang menyatakan usia berpengaruh negatif dan signifikan terhadap keputusan pengambilan kredit usaha.

\section{Pengaruh Pendapatan Terhadap Keputusan Pengambilan Kredit Usaha}

Diperoleh nilai $t_{\text {hitung }}-0,851$ sedangkan $t_{\text {tabel }}$ sebesar 1,652 . Hal ini berarti $t_{\text {hitung }}<t_{\text {tabel }}$ sedangkan signifikansi 0,396 lebih dari 0,05. Oleh karena $t_{\text {hitung }}<t_{\text {tabel }}(-0,851<1,652)$ artinya secara parsial ada pengaruh negatif dan tidak signifikan antara faktor demografi : pendapatan terhadap keputusan pengambilan kredit usaha sehingga hipotesis ditolak dan Ho diterima.

Seseorang yang memiliki pendapatan lebih tinggi memiliki kemampuan untuk membiayai sendiri usaha mereka karena mampu membutuhkan modal dengan menggunakan pendapatan sendiri, Sehingga mereka tidak mengambil kredit. Ketika tingkat pendapatan meningkat, keputusan pengambilan kredit menurun. Hasil ini selaras dengan 
Jurnal Manajemen Bisnis, Vol 10. No.1, Maret 2019, E-ISSN:2622-6308 P-ISSN:2086-8200

Website: http://journal.umy.ac.id/index.php/mb

DOI:10.18196/mb.10169

penelitian yang dilakukan oleh Saqib, Kowurnu, Panezia dan Ali (2017) bahwa pendapatan berpengaruh negatif dan tidak signifikan terhadap keputusan pengambilan kredit.

\section{Pengaruh Pekerjaan Terhadap Keputusan Pengambilan Kredit Usaha}

Diperoleh nilai $t_{\text {hitung }} 2,756$ sedangkan $t_{\text {tabel }}$ sebesar 1,652. Hal ini berarti $t_{\text {hitung }}>t_{\text {tabel }}$ sedangkan signifikansi 0,006 kurang dari 0,05. Oleh karena $t_{\text {hitung }}>t_{\text {tabel }}(2,756>1,652)$ artinya secara parsial ada pengaruh positif signifikan antara faktor demografi : pekerjaan terhadap keputusan pengambilan kredit usaha, sehingga hipotesis ditolak dan Ho diterima.

Hasil penelitian ini menyebutkan bahwa yang bekerja sebagai pedagang kaki lima tetap akan mengambil kredit untuk memenuhi kebutuhan modal. Sehingga pekerjaan yang disandang tidak memiliki perbedaan dan akan mempengaruhi pengambilan kredit. Hasil penelitian ini di dukung oleh Teori Analisis Kredit 5C yang Collateral. Pekerjaan termasuk collateral karena dalam melakukan kredit perlu adanya jaminan. Jaminan diberikan sebagai pengaman kredit yang diberikan oleh lembaga keuangan. Pekerjaan menjadi sumber utama untuk dapat memenuhi kewajibannya dalam mengembalikan pinjaman dari pihak bank maupun lembaga keuangan lainnya sehingga jaminan yang diberikan dapat kembali terhadap yang mengambil kredit.

\section{Pengaruh Pendidikan Terhadap Keputusan Pengambilan Kredit Usaha}

Diperoleh nilai $t_{\text {hitung }} 1,292$ sedangkan $t_{\text {tabel }}$ sebesar 1,652. Hal ini berarti $t_{\text {hitung }}<t_{\text {tabel }}$ sedangkan signifikansi 0,198 lebih dari 0,05. Oleh karena $t_{\text {hitung }}<t_{\text {tabel }}(1,292<1,652)$ artinya secara parsial ada pengaruh positif tidak signifikan antara faktor demografi : pendidikan terhadap keputusan pengambilan kredit usaha sehingga hipotesis ditolak dan Ho diterima.

Tingkat pendidikan mampu mempengaruhi kemampuan masyarakat dalam mempertimbangkan dan mengambil keputusan untuk menentukan kredit yang diambil. Dengan semakin tinggi tingkat pendidikan yang dicapai maka semakin banyak pengetahuan yang diperoleh untuk bertindak ataupun mengambil keputusan akan lebih teliti dalam mempertimbangkan segala keputusan seperti keputusan mengambil kredit dengan memperhatikan prosedur pembayaraan, manfaat, dan risko keuangan mengenai bunga yang ditetapkan.

Hasil penelitian ini didukung oleh penelitian Pranata dan Widarno (2014) bahwa pendidikan berpengaruh positif dan tidak signifikan terhadap keputusan pengambilan kredit usaha. Hasil ini didukung oleh teori pengambilan keputusan. Menurut Simon (1960) 
Jurnal Manajemen Bisnis, Vol 10. No.1, Maret 2019, E-ISSN:2622-6308 P-ISSN:2086-8200

Website: http://journal.umy.ac.id/index.php/mb

DOI:10.18196/mb.10169

tahap dalam pengambilan keputusan ada 4, salah satunya intelligence. Intelligence menjadi proses pengumpulan informasi yang bertujuan mengidentifikasi permasalahan. Dengan semakin tinggi pendidikan, dapat dikatakan juga semakin tinggi pemahaman mengenai keputusan pengambilan kredit usaha (Fahmi, 2016).

\section{Pengaruh Akses Permodalan Terhadap Keputusan Pengambilan Kredit Usaha}

Diperoleh nilai $t_{\text {hitung }} 4,297$ sedangkan $t_{\text {tabel }}$ sebesar 1,652. Hal ini berarti $t_{\text {hitung }}>t_{\text {tabel }}$ sedangkan signifikansi 0,000 kurang dari 0,05. Oleh karena $t_{\text {hitung }}>t_{\text {tabel }}(4,297>1,652)$ artinya secara parsial ada pengaruh positif dan signifikan antara akses permodalan terhadap keputusan pengambilan kredit usaha, sehinggga hipotesis diterima dan Ho ditolak.

Secara ekonomi, pedagang kaki lima yang menghadapi kendala dalam modal cenderung mengakses banyak sumber dana alternatif untuk memenuhi kebutuhan modal mereka. Salah satunya adalah dengan mengambil keputusuan untuk melakukan kredit pada lembaga keuangan. Akan tetapi, akses yang mereka lakukan cukup sulit karena terkendala pada usaha mereka yang bersifat informal.

Hasil penlitian ini didukung oleh Nguyen dan Luu (2013) dan Heikkila, Kalmi dan Ruuskanen (2016) akses permodalan berpengaruh positif dan signifikan terhadap keputusan pengambilan kredit usaha.

\section{KESIMPULAN}

Berdasarkan analisis data dan pembahasan yang telah dilakukan maka dapat ditarik kesimpulan sebagai berikut: (1) Literasi keuangan, faktor demografi (usia, pendapatan, pekerjaan dan pendidikan) dan akses permodalan secara bersama-sama berpengaruh positif signifikan secara simulan terhadap keputusan pengambilan kredit usaha. (2) Literasi keuangan berpengaruh positif dan signifikan terhadap keputusan pengambilan kredit usaha. (3) Faktor demogarfi : usia berpengaruh negatif dan signifikan terhadap keputusan pengambilan kredit usaha. (4) Faktor demografi : pendapatan berpengaruh negatif dan tidak signifikan terhadap keputusan pengambilan kredit usaha. (5) Faktor demografi : pekerjaan berpengaruh positif dan signifikan terhadap keputusan pengambilan kredit usaha. (6) Faktor demografi : pendidikan berpengaruh positif dan tidak signifikan terhadap keputusan 
Jurnal Manajemen Bisnis, Vol 10. No.1, Maret 2019, E-ISSN:2622-6308 P-ISSN:2086-8200

Website: http://journal.umy.ac.id/index.php/mb

DOI:10.18196/mb.10169

pengambilan kredit usaha. (7) Akses permodalan berpengaruh positif dan signifikan terhadap keputusan pengambilan kredit usaha.

\section{DAFTAR PUSTAKA}

Aminatuzzahra. (2014). Persepsi Pengaruh Pengetahuan Keuangan, Sikap Keuangan, Sosial Demografi Terhadap Perilaku Keuangan Dalam Pengambilan Keputusan Investasi Individu (Studi Kasus Pada Mahasiswa Magister Manajemen Universitas Diponegoro). Jurnal Bisnis STRATEGI. Volume 23 No. 2 Des. 2014

Andriani, T. Y., \& Cholid, I. (2016). Pengaruh Literasi Keuangan dan Faktor Demografi Terhadap Keputusan Pengambilan Kredit ( Sudi Kasus Nasabah Bess Finance Palembang ), (x), 1-14.

Brealey RA, Myers SC, and Allen F. (2008). Principles of Corporate Finance - 9th Edition. McGraw-Hill/Irwin, New York

Chandio, A. A., Jiang, Y., Wei, F., Rehman, A., \& Liu, D. (2017). Famers' access to credit: Does collateral matter or cash flow matter? - Evidence from Sindh, Pakistan. Cogent Economics \& Finance, 5(1), 1369383.

Chrisanti, Y. M., \& Saryadi, S. (2017). Pengaruh Tingkat Suku Bunga, Kualitas Pelayanan Dan Pendapatan Usaha Terhadap Keputusan Pengambilan Kredit (Studi Kasus Pada Nasabah Bni Kcu Undip Semarang). Jurnal Ilmu Administrasi Bisnis, 6(3), 666-675.

Dewa Made. (2015). Konsep Dasar Sektor Informal dan Ciri-Ciri dan Peran Sektor Informal. www.hestanto.web.id

Ghozali, Imam (2016). Aplikasi Analisis Multivariate Dengan Program SPSS. Semarang : BP Universitas Diponegoro.

Hanifah, Riska. "Implementasi Metode Promethee dalam penentuan penerima kredit usaha rakyat (KUR)." (2015).

Heikkilä, A., Kalmi, P., \& Ruuskanen, O. P. (2016). Social capital and access to credit: Evidence from Uganda. The Journal of Development Studies, 52(9), 1273-1288.

Hidajat, Taufik. 2016. Literasi Keuangan. Semarang: STIE Bank BPD Jateng

Hidayati, F. F., \& Kartawinata, B. R. (2017). Demografi Terhadap Proses Keputusan Pengambilan Kredit Usaha Rakyat ( Kur ) Pada Bank Rakyat Indonesia ( Bri ) Kantor Unit Mantingan, Kabupaten Ngawi Jawa Timur, 10, 1-10.

Hue, T. H. T., \& Phuong, N. T. M. (2014). The impact of demographical factors on investment decision: a study of Vietnam stock market.

Irham fahmi, 2016. Teori Dan Teknik Pengambilan Keputusan Kualitatif Dan Kuantitatif. Jakarta;Rajagrafindo Persada

Iswantoro dan Anastasia (2013). Hubungan demografi, anggota keluarga dan situasi dalam pengambilan keputusan pendanaan pembelian rumah tinggal Surabaya. Jurnal Finesta. 1(2), 124-129.

Keputusan Menteri Keuangan No. 40/KMK.06/2003 tanggal 29 Januari 2003

Korutaro Nkundabanyanga, S., Kasozi, D., Nalukenge, I., \& Tauringana, V. (2014). Lending terms, financial literacy and formal credit accessibility. International Journal of Social Economics, 41(5), 342-361.

Kurniawan, B. J., Suryoko, S., \& Listyorini, S. (2016). PT. Bank Tabungan Negara (Persero) Tbk Kantor Cabang Semarang. Jurnal Ilmu Administrasi Bisnis, 5(4), 562-570.

Lusimbo, N. E., \& Muturi, W. (2015). Financial Literacy and The Growth of Small Enterprises in Kenya: A Case of Kakamega Central Sub-Country, Kenya. International Journal of Economics, Commerce and Management, 828-845. 
Jurnal Manajemen Bisnis, Vol 10. No.1, Maret 2019, E-ISSN:2622-6308 P-ISSN:2086-8200

Website: http://journal.umy.ac.id/index.php/mb

DOI:10.18196/mb.10169

Lusardi, A., \& Mitchell, O. S. (2014). The economic importance of financial literacy: Theory and evidence. Journal of economic literature, 52(1), 5-44.

Mardiyatmo.(2008). kewirausahaan.Surakarta:Yudhistira

Margaretha, F., \& Arif. (2015). Tingkat Literasi Keuangan Pada Mahasiswa S-1 Fakultas Ekonomi. Jurnal Manajemen dan Kewirausahaan, 17(1), 76-85.

Myers, Stewart C.; Majluf, Nicholas S. (1984). "Corporate financing and investment decisions when firms have information that investors do not have". Journal of Financial Economics. 13 (2): 187-221. doi:10.1016/0304-405X(84)90023-0. hdl:1721.1/2068.

Nasution, A. P. (2016). Pemberdayaan Sektor Ekonomi Informal: Suatu Tinjauan Empiris. Jurnal Dimensi, 4(2).

Nikaido, Y., Pais, J., \& Sarma, M. (2015). What hinders and what enhances small enterprises' access to formal credit in India?. Review of Development Finance, 5(1), 43-52.

Nguyen, N., \& Luu, N. T. H. (2013). Determinants of financing pattern and access to formalinformal credit: the case of small and medium sized enterprises in Viet Nam. Journal of Management Research, 5(2), 240-259.

OJK. 2018. https://www.ojk.go.id/id/data-dan-statistik/ojk/default.aspx

Oktavianti, V., Hakim, M. ., \& Kunaifi, A. (2017). Pengaruh Literasi Keuangan dan ersyaratan Kredit terhadap Akses Kredit Formal pada UMKM di Surabaya. JURNAL SAINS DAN SENI ITS, 6(1), 1-5.

Ridlwan, A. A. (2016). Implementation Akad Muzara'ah In Islamic Bank: Alternative To Access Capital Agricultural Sector. Iqtishoduna: Jurnal Ekonomi Islam, 7(1), 34-48.

Sadiq, M. N., \& Ishaq, H. M. (2014). The Effect of Demographic Factors on the Behaviour of Investors during the Choice of Investments: Evidence from Twin Cities of Pakistan. Global Journal of Management And Business Research.

Saqib, S. E., Kuwornu, J. K., Panezia, S., \& Ali, U. (2018). Factors determining subsistence farmers' access to agricultural credit in flood-prone areas of Pakistan. Kasetsart Journal of Social Sciences, 39(2), 262-268.

Sujarweni, V. Wiratna. (2015). Metodologi Penelitian Bisnis \& Ekonomi. Yogyakarta: Pustakabarupres

Suliyanto. 2018. Metode Penelitian Bisnis.Netode Penelitian Bisnis Untuk Skripsi, Tesis Dan Disertasi. Yogyakarta: Andi

Suliyanto. 2011. Ekonometrika Terapan : Teori dan Aplikasi dengan SPSS. Yogyakrta: Andi

Tsalista Alina, Rachmansyah Yanuar, (2016) Analisis Pengaruh Literasi Keuangan Dan Faktor Demografi Terhadap Pengambilan KreditPada Pt. Columbia Cabang Kudus; Jurnal Media Ekonomi dan Manajemen Vol 3 No 1 ISSN.0854-1442

Undang-Undang No. 9 Tahun 1995

Winanto, A. R., \& Rapini, T. (2016). Peran Lembaga Keuangan Informal Terhadap Pemberdayaan Kelompok Usaha Informal. Ekuilibrium: Jurnal Ilmiah Bidang Ilmu Ekonomi, 9(1), 1-9.

Wiryaningtyas Dwi Perwitasari. (2016). Pengaruh Keputusan Nasabah Dalam Pengambilan Kredit pada Bank Kredit Desa Kabupaten Jember. Jurnal Ekonomi dan Bisnis GROWTH Vol. 14, No. 2 :49-57

Wijayanto Kusuma. (2015). Pengaruh Kualitas Pelayanan Terhadap Kepuasan dan Loyalitas Nasabah Bank. Jurnal Ekonomi Manajemen Sumber Daya Vol. 17, No. 1,

(https:// www.hestanto.web.id/ciri-dan-peran-sektor-informal/).

(https:// www.ojk.go.id/id/kanal/edukasidanperlindungankonsumen/Pages/literasikeuangan.aspx) 